\title{
A minimális reziduális betegség vizsgálata krónikus limfoid leukémiában
}

\author{
Takács Ferenc ${ }^{1}$, Kardos Ilona $^{1}$, Czeti Ágnes ${ }^{1}$, Aczél Dóra ${ }^{2}$, Illés Sarolta ${ }^{3}$, \\ Balogh Alexandra ${ }^{3}$, Gaál-Weisinger Júlia ${ }^{4}$, Szalóki Gábor ${ }^{1}, B$ Barna Gábor ${ }^{1} @$ \\ 'Semmelweis Egyetem, I. sz. Patológiai és Kísérleti Rákkutató Intézet, Budapest \\ ${ }^{2}$ Semmelweis Egyetem, I. sz. Patológiai és Kísérleti Rákkutató Intézet, \\ MTA-SE Lendület Molekuláris Onkohematológia Kutatócsoport, Budapest \\ ${ }^{3}$ Semmelweis Egyetem, III. sz. Belgyógyászati Klinika, Budapest \\ ${ }^{4}$ Semmelweis Egyetem, I. sz. Belgyógyászati Klinika, Budapest
}

\begin{abstract}
A krónikus limfoid leukémia (CLL) a leggyakoribb felnőttkori leukémia a fejlett országokban. A CLL egy indolens lefolyású, gyógyíthatatlan betegség, mely a kezelést követő relapszusokkal járhat, emiatt a betegek folyamatos követése szükséges. Az elmúlt évek bővülő terápiás lehetőségei (pl.: alemtuzumab, venetoclax) lehetővé tették a daganatos sejtek mennyiségének tartós és drasztikus csökkenését, ezért szükségessé vált a visszatérő betegség minél érzékenyebb detektálása. Erre nyújt lehetőséget a minimális, újabban mérhető reziduális betegség (minimal residual disease: MRD) meghatározása áramlási citometriai és molekuláris genetikai vizsgálati módszerekkel. Az MRD-szint és a túlélés összefüggését vizsgáló klinikai tanulmányok egyértelművé tették, hogy az alacsonyabb MRD-szint hosszabb túléléssel jár együtt. Bár az MRD meghatározása jelenleg nem a klinikai rutin része, amennyiben a jelenleg még futó klinikai vizsgálatok eredményei indokolttá teszik meghatározását, áramlási citometriai módszeren alapuló vizsgálata a rutin diagnosztika része lehet majd.
\end{abstract}

Kulcsszavak: CLL, MRD, áramlási citometria

\section{The role of minimal residual disease in chronic lymphocytic leukemia}

Chronic lymphoid leukemia (CLL) is the most common adult leukemia in developed countries. The CLL is an indolent but incurable disease that has relapses during the treatment, which causes the need of the patient's continuous follow-up. The expanding therapeutic potential of recent years (i.e. alemtuzumab, venetoclax) has made it possible to permanently and drastically reduce the number of tumor cells, thus it has become necessary to detect the recurrent disease as precisely as possible. Measuring minimal residual disease (novel definition measurable residual disease: MRD) with flow cytometric and molecular genetic methods gives an opportunity to make this happen. Clinical studies investigating the association between MRD level and survival have shown that lower MRD level is associated with longer survival. Although determination of MRD is not the part of the clinical routine if the results of clinical investigations in progress make its determination justified, MRD measurement based on the flow cytometric method could be the part of the routine diagnostic procedure.

Keywords: CLL, MRD, flow cytometry

(Beérkezett: 2019. október 29.; elfogadva: 2020. március 1.)

\footnotetext{
@ Levelezési cím: Dr. Barna Gábor, Semmelweis Egyetem, I. sz. Patológiai és Kísérleti Rákkutató Intézet, 1085 Budapest, Üllői út $26 .$, Tel.: +36-1-215-7300/54421; E-mail: barna.gabor@med.semmelweis-univ.hu
} 


\section{Rövidítések}

ALL = akut limfoblasztos leukémia; Allo-HSCT = allogen hematopoetic stem cell transplantation, allogén őssejtátültetés; $\mathrm{AML}=$ akut mieloid leukémia; $\mathrm{BTK}=$ Bruton-tirozin-kináz; CLL = krónikus limfoid leukémia; $\mathrm{CR}=$ complete remission, komplett remisszió; ERIC = European Research Initiative on CLL, Európai CLL Kutatóhálózat; FCA = fludarabin-ciklofoszfamid-alemtuzumab; FCM = flow cytometry, áramlási citometria; $\mathrm{FCR}=$ fludarabin-ciklofoszfamid-rituximab; HTS = high throughput sequencing, nagy áteresztőképességű szekvenálás; MRD = minimális reziduális betegség; OS = overall survival teljes túlélés; PBSCT = peripheral blood stem cell transplantation, perifériás vér őssejtátültetés; $\mathrm{PCR}=$ polimerase láncreakció; $\mathrm{PFS}=$ progression free survival, progressziómentes túlélés; $\mathrm{PR}=$ partial remission, parciális remisszió $; \mathrm{RB}=$ rituximab-bendamustin

\section{Bevezetés}

Az elmúlt években a molekuláris diagnosztikában bekövetkezett robbanásszerü fejlődés eredményeként új prognosztikus faktorok kerültek a kutatás homlokterébe a hematoonkológiában. Ezek közül az egyik az akut limfoblasztos leukémia (ALL) és akut mieloid leukémia (AML) esetén már használt minimális reziduális betegség (MRD) mérése áramlási citometriai módszerrel krónikus limfoid leukémiában (CLL). Az MRD meghatározása során a cél a kezelés ellenére még a szervezetben maradt daganatos sejtek kimutatása. Már 1992-ben publikáltak MRD meghatározásáról CLL-ben, azonban a csontvelői minták és a viszonylag kis esetszám, továbbá csak két marker expressziójának a vizsgálata miatt akkor még áramlási citometriai detektálása csak távoli lehetőségként merült fel [1]. A klinikai alkalmazás irányába történő jelentős előrelépésre a kétezres évek elejéig kellett várni, amikor Andy Rawstron és munkatársai kutatásuk eredményeképpen felvetették az MRD használatának lehetőségét a kezelés optimalizálásával kapcsolatban [2]. Rawstron és munkacsoportja vizsgálatában komplett remissziót (CR) a betegek kemoterápia, illetve csontvelő-transzplantáció (peripheral blood stem cell transplantation: PBSCT) következtében értek el, azonban a kemoterápia nagy rizikóval jár az idősebb betegek esetében. A kemoterápia nélküli hosszabb túlélés lehetőségét a CD52-ellenes alemtuzumab megjelenése hozta el szintén a kétezres évek elején. Az ezzel kapcsolatos klinikai vizsgálatban az alemtuzumabkezelésben részesülő betegeknek nagyobb volt a progressziómentes túlélése (progression free survival: PFS), mint a klorambucil kemoterápiát kapóknak [3]. A kétezres évek során több klinikai vizsgálat eredményeképpen felmerült az MRD prognosztikus szerepe CLLben. Ezek egyike a CLL8 tanulmány volt, melynek eredményeképpen Böttcher és munkatársai publikálták, hogy az MRD-szint független előrejelzője a progressziómentes túlélésnek és a teljes túlélésnek (overall survival: OS) is [4]. Az MRD vizsgálatának az új korszakát az elmúlt években megjelent Bcl-2-gátló gyógyszerek (pl. venetoclax) klinikai alkalmazása hozta el. Venetoclax-kezelés hatására még a rossz prognózisú (pl. p53-defektusos) betegek esetében is a CLL sejtszám nem detektálható szintre csökkent [5]. Kijelenthető, hogy bár jelenleg az MRD meghatározása nem a rutindiagnosztika része, azonban konvencionális kemoimmuno-terápia mellett megjelent Bcl-2gátló gyógyszerek drasztikus CLL sejtszám csökkentő hatása miatt a közeljövőben szükségessé válhat $a z$ MRD-panelek alkalmazása célzott esetekben a klinikai gyakorlatban is.

\section{MRD meghatározása a klinikai vizsgálatok tükrében}

Az MRD prognosztikus szerepét vizsgáló klinikai tanulmányok során detektálási küszöbnek a $10^{-4}$ értéket tekintették [6]. $10^{-4}$ érzékenységi szint alatt nem detektálható (undetectable minimal residual disease: uMRD), ezen érték fölött detektálható (detectable minimal residual disease: dMRD) MRD-ről beszélhetünk. A korábban már említett CLL8 tanulmányban Böttcher és munkatársai azt találták, hogy fludarabin-ciklofoszfamid-rituximab (FCR) kemoimmuno-terápiát követően a betegek többségében (63\%) uMRD alakult ki. Vizsgálatuk alapján az uMRD-szint független előrejelzője volt a progressziómentes túlélésnek, valamint a teljes túlélésnek is. uMRD esetén mérték a leghosszabb PFS-t (68,7 hónap), míg ezek az értékek jelentősen kisebbek voltak a közepes (40,5 hónap), illetve a magas (15,4 hónap) MRD-jü csoportban. Az OS 48,4 hónap volt a magas MRD-jü csoportban, míg közepes uMRD esetén a vizsgálati időben a betegek többsége még életben volt [4]. Kwok és munkatársai többszörös kemoimmuno-terápiában részesülő betegek esetében elemezték, hogy az MRD-státusz függvényében hogyan alakult a betegek progressziómentes és teljes túlélése. Kutatásuk során azt találták, hogy uMRD esetében hosszabb volt a 10 éves PFS (65\% vs. $10 \%)$ és a 10 éves OS (70\% vs. $30 \%)$ is, mint dMRD esetében [7]. A későbbi CLL10 tanulmány keretében Eichorst és munkatársai az FCR-kezelést hasonlították össze rituximab-bendamustin- (RB-) kezeléssel. Megállapították, hogy FCRkezelés során gyakoribb volt az uMRD (74\%), mint RB-kezelés esetében (63\%) [8]. Rituximab helyett alemtuzumabot bevezetve Geisler és munkacsoportja megállapította, hogy fludarabin-ciklofoszfamid-alemtuzumab(FCA-) kezelést követően több esetben alakult ki uMRD, mint csupán fludarabint és ciklofoszmaidot (FC) kombináló kezelésnél (64\% vs. 43\%) [9]. Az elmúlt években a kemoimmuno-terápia mellett megjelentek a CLL-kezelési palettáján a célzott terápiás készítmények, akár első vonalban választhatóként. Ezért ezeknél a gyógyszereknél is felmerült az MRD meghatározásának a lehetősége, és prognosztikus jelentőségének a vizsgálata. A hagyományos kemoimmuno-terápiától eltérő kezelés hatásait vizsgálva Roberts és munkatársai a Bcl-2-gátló venetoclaxszal kezelt betegek eredményeit elemezték. Vizsgála- 
tuk során azt tapasztalták, hogy a betegek 5\%-a esetében alakult ki csontvelői uMRD [10]. A Murano-vizsgálatban 18 hónapot követően a rituximab-venetoclax kombináció esetében jelentősen nagyobb volt az MRD-negatív esetek száma, mint az RB-kezelés esetén (59,8\% vs. 5,1\%) [11]. Kovacs és munkatársai a klinikai remissziót tekintve erős összefüggést találtak a remisszió mértéke és az MRD szintje között. A részleges és teljes remisszió meghatározásuk a 2008-as CLL ajánláson alapult, amely labor paramétereket, fizikális vizsgálati és CT-eredményeket vesz figyelembe [12]. Vizsgálatuk során azt tapasztalták, hogy nem volt szignifikáns különbség a PFS-ben a részleges remissziót (partial remission: $\mathrm{PR}$ ), valamint a teljes remissziót (complete remission: $\mathrm{CR}$ ) mutató csoportban, amennyiben uMRD állt fent. Azonban uMRD melletti PR hosszabb PFS-t eredményezett, mint dMRD melletti CR [13]. Ezek az eredmények arra utalnak, hogy amennyiben a kezelések hatására jelentősen lecsökken a CLL-sejtek száma, az MRD-szint mértéke pontosabb képet adhat a remisszió mértékéről, mint a klinikai gyakorlatban használt CR- és PR-érték. Az MRD-meghatározás optimális idejével kapcsolatban jelenleg nincs egyértelmü ajánlás a nemzetközi irodalomban. A legfrissebb 2018-as CLL ajánlásban sem található egyértelmű iránymutatás vizsgálat időpontjára [6]. Az eddigi eredmények alapján a vizsgálat idejét a választott kezelés típusa és a beteg klinikai állapota határozza meg, amit minden betegnél egyénileg kell mérlegelni [14]. Az MRD meghatározásának CLL-ben külön jelentőséget adott, hogy az európai gyógyszerügynökség (European Medicines Agency: EMA) 2016-ban elfogadta intermedier végpontként az MRD áramlási citometriai (flow cytometry: FCM) alapú meghatározását a PFS helyettesítésére a klinikai vizsgálatokban [15-17]. Ilyen állásfoglalást nagyon ritkán fogalmaz meg az EMA, és ennek igen nagy klinikai jelentősége van. Intermedier végpontként az MRD-meghatározás lehetővé teszi egy klinikai vizsgálat lezárását, és az adott gyógyszer korábbi engedélyeztetését. Az elmúlt években futott Murano-vizsgálat során a venetoclax-rituximab kombinációra való jó válasz következtében felmerült a fix idejü kezelés alkalmazása CLL-ben [11]. A fix idejü kezelési séma előnyei közé tartozik a folyamatos kezelés kiváltotta rezisztencia lehetőségének a csökkenése, továbbá a gyógyszer okozta toxicitás mérséklése. E kezelési séma során kulcsszerep juthat az MRD meghatározásának. Fix idejü kezelés végén a gyógyszer elhagyásra kerülhet, ezért az MRD-szint függvényében lehet dönteni a kezelés folytatásáról vagy befejezéséről, vagyis ebben az esetben felmerül az MRD-vezérelt kezelés lehetősége [14, 18]. CLL kezelésében az elmúlt években a másik rendkívül hatékony elsőnek választandó szer a Bruton-tirozin-kináz- (BTK-) gátló ibrutinib. Az ibrutinibkezelés hatékonyságát több klinikai vizsgálat is igazolta [19, 20], azonban BTK-gátlás hatására az esetek többségében nem volt elérhető uMRD-szint [21]. Továbbá egy másik klinikai vizsgálat megmutatta, hogy nincs jelentős különbség az uMRD- és a dMRD-státuszú ibrutinibbel kezelt betegek túlélése között [22]. Ezen eredmények alapján ibru- tinibkezelés esetén az MRD meghatározása a terápiás döntést nem segíti, ezért rutinszerü alkalmazása nem indokolt. Azonban ibrutinib és venetoclax kombinációs kezelés során felvetődik a két gyógyszer szinergikus hatása. A Clarity-vizsgálat során az ibrutinib-venetoclax kombinált kezelésben részesülő betegek több mint $60 \%$-a mutatott perifériás vér MRD-negativitást, míg több mint $40 \%$-a csontvelői MRD-negativitást. [23]. Ezért ibrutinib-venetoclax kombinációs kezelést kapó betegek esetében is felvetődik az MRD-mérés jelentősége. Ehhez azonban mindenképpen meg kell várni néhány klinikai vizsgálat (pl. Captivate) lezárulását. Venetoclax okozta tartós MRD-negativitás kapcsán felvetődik a CLL gyógyulásának a kérdése. Hagyományos RFC-kezelés hatására is elérhető volt akár 15 éves túlélés [24], azonban gyakoriak voltak a relapszusok, és mivel az ismétlődő kemoterápia fokozza a genetikai mutációk kialakulását, a másodvonalban alkalmazandó innovatív gyógyszerekre kialakuló rezisztenciának nő az esélye. A venetoclax ilyen genotoxikus hatás nélkül képes hosszú progressziómentes és teljes túlélést elérni, melynek jele a tartós MRD-negativitás [25]. A célzott terápiás gyógyszerek színpadra lépésével a kemoterápiát nem toleráló idős, komorbid betegek is esélyt kaptak a hosszabb túlélésre. Azonban bármennyire is jól tolerálható gyógyszer a venetoclax, képes jelentős citopéniát okozni, mely esetben mindenképp felfüggesztendő a kezelés. Ebben az esetben nem lehet terápiás cél az MRD-negativitás, csak a jó betegségkontrol [14].

\section{Az MRD meghatározásának módjai}

Az Európai CLL Kutatóhálózat (European Research Initiative on CLL: ERIC) ajánlása alapján az MRD-meghatározásnál a szükséges érzékenységi szint $10^{-4}$, vagyis a megbízható eredményekhez 1 pozitív eseményt kell megtalálni 10000 negatív mellett. A mérésre használt módszereknél fontos a nagy szenzitivitás és specificitás [26]. Ilyen mértékü szenzitivitásra a rutindiagnosztika során alkalmazott metodikai módszerek közül az áramlási citometria, a kvantitatív polimeráz láncreakció (quantitative polimerase chain reaction: qPCR) képes. Jelenleg nem a rutindiagnosztika része, azonban publikáltak eredményeket MRD meghatározására CLL-ben high throughput sequencing (HTS) módszer alkalmazásával [18, 27-29]. Az FCM-et és a PCR-t összehasonlítva megfigyelhető, hogy MRD-detektálás szempontjából jó korrelációt mutatnak az eredmények egymással $(r=0,93)$. Böttcher és munkatársai PCR-vizsgálatok során a CLL-specifikus IgH génátrendeződést vizsgálták, és ezek a vizsgálatok érzékenyebbnek mutatkoztak a betegség detektálása szempontjából a $10^{-4}$ szintnél. Ezenkívül Allo-HSCT-t követően a PCR-vizsgálatok korábban jelezték a relapszust az áramlási citometriai vizsgálatokkal szemben [30]. Azonban a molekuláris vizsgálatok sem tökéletesek. Hátrányaik közé tartozik többek között, hogy az IgH génátrendeződés vizsgálatához szükséges egy referenciaminta, amely- 
hez viszonyítani lehet a későbbi eredményeket [28]. Ezért molekuláris technikákkal kizárólag ismert, CLL-re specifikus IgH génátrendeződéssel rendelkező betegek követése valósítható meg. Továbbá jelentős idő-, munka- és pénzigényes metodikák. A HTS módszerrel akár $10^{-6}$ érzékenység is elérhető, azonban ezzel a metodikával kapcsolatban jelenleg kevés klinikai eredmény áll rendelkezésre, ezért még nem kellően standardizált módszer. Továbbá klinikai vizsgálatok nem igazolták még minden kétséget kizárólag a nagyobb szenzitivitás klinikai előnyét [18]. Tekintettel arra, hogy a HTS-vizsgálat bár nagyobb szenzitivitású, de széleskörüen nem elterjedt, továbbá jelentős pénz- és munkaigényes, ezért jelenleg még nem képes kiváltani az FCM-alapú MRD-meghatározást. Áramlási citometriai vizsgálat során a sejtek immunfenotípusa kerül meghatározásra, ami nem igényel referenciamintákat. Az említett metodikák összehasonlítását az 1. táblázat tartalmazza. Fenotípus alapján a CLL-sejtek CD19 és CD5 kettős pozitív érett B-sejtek, melyek erősen expresszálják a CD43 és a ROR1 markereket, míg CD79b, CD81, CD20 és CD22 szempontjából gyenge expressziót mutatnak (1. ábra). Ezeknek a markereknek a használatával el lehet különíteni a CLL-sejteket az egészséges B-sejtektől, a T-sejtektől, valamint más leukémiás sejtektől. Az ERIC csoport 6 színú áramlási citometriai mérése
1. táblázat. A metodikák összehasonlítása

\begin{tabular}{lll}
\hline Tulajdonságok & $\begin{array}{c}\text { Áramlási } \\
\text { citometria }\end{array}$ & Molekuláris \\
\hline ERIC alapján kellően szenzitív-e & igen & igen \\
Maximális szenzitivitás & $10^{-5}$ & $10^{-6}$ \\
Vérmintából használható & igen & igen \\
Csontvelői mintából használható & igen & igen \\
Szükséges-e referenciaminta & nem & igen \\
Turnaround time & $12-24$ óra & $7-14$ nap \\
\hline
\end{tabular}

során a CD19, CD5, CD20 markerek kombinációját javasolja vagy a CD3, CD38, CD79b, vagy a CD81, CD22 és CD43 markerekkel együtt az MRD-detektálásához. Patz és munkatársainak a vizsgálata kimutatta, hogy ezeken a markereken túl a ROR-1 expresszió segítségével nagyon érzékenyen meg lehet találni a CLL-sejteket MRD-vizsgálat során [14, 31-34]. Ezeket az ajánlásokat követve alakította ki az ország több áramlási citometriai laboratóriuma (pl.: SE I. sz. Patológiai Intézet, Dél-pesti Centrumkórház, DE Labormedicina Intézet, PTE I. sz. Patológiai Intézet) MRD-detektálási paneljét, esetenként membránpermeábilis sejtmagfestékkel kiegészítve.

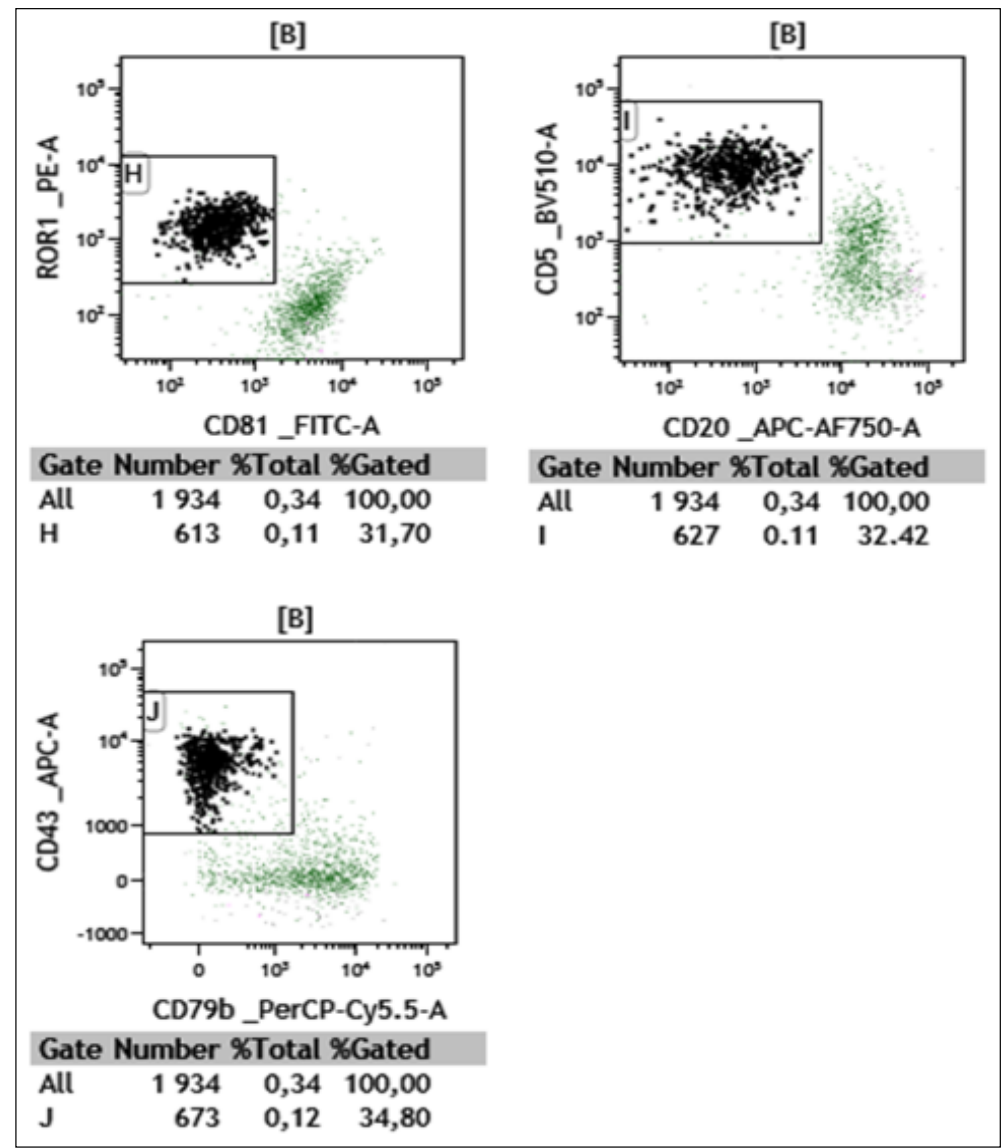

1. ábra. CLL MRD meghatározása során használt kapuzási stratégia. Feketével vannak jelölve a CLL-sejtek (CD5-, CD43-, ROR1-pozitív, CD81-, CD79b-, CD20-negatív). A dotplotok az összes SYTO-pozitív esemény közül a CD19-pozitívakat, CD3-negatívakat mutatják 


\section{MRD-vizsgálat: csontvelő vagy perifériás vér?}

A klinikai vizsgálatokban MRD meghatározására CLLben perifériás vér- és csontvelői mintát használnak. Abrisqueta és munkatársai vizsgálatuk során azt találták, hogy kemoimmuno-terápiával (FCR) kezelt CLL-es betegeknél, bár az esetek $21 \%$-ában a perifériás vérminta MRD-negatív volt, a csontvelőben MRD-pozitivitás volt kimutatható. A csontvelői MRD-negativitás viszont minden esetben perifériás vér MRD-negativitással társult [35]. Fischer és munkatársai vizsgálatuk során azt tapasztalták, hogy perifériás vérminta esetén 57,8\%-ban állt fenn MRD-negativitás, míg csontvelői minta esetén ez az arány 29,2\%-nak adódott [36]. További kutatások megerősítették, hogy a perifériás vérminta eredményei jó korrelációt mutatnak a csontvelői minta eredményeivel (konkordancia 87\%) [27], továbbá mind a perifériás vérmintából, mind a csontvelői mintából mért MRD erős prediktora a PFS-nek és az OS-nek [26]. A vér- és csontvelővizsgálat közötti eltérő eredményt magyarázhatja a kompartmenthatás. Ez azt jelenti, hogy az eltérő gyógyszerek eltérő farmakokinetikai tulajdonságuk következtében másképp kumulálódnak a különböző szövetekben. Li és munkatársai egy négykaros vizsgálat során megállapították, hogy CLLben a ciklofoszfamid szérum koncentrációja a rituximab hozzáadásával emelkedett, míg a fludarabiné csökkent [37]. Ez az eredmény magyarázatot adhat arra, hogy ugyanaz a kezelés más mértékü tumorsejt-eliminációhoz vezet az eltérő kompartmentekben, így az MRD mértéke a perifériás vérben vagy a csontvelőben különbözhet [13]. Tekintettel arra, hogy CLL esetében ritkán történik csontvelői mintavétel, így a perifériás vér vizsgálata könnyebben kivitelezhető a mindennapi gyakorlatban. Ez a szemlélet tükröződik a 2018-as CLL ajánlásban is, ami a perifériás vérminta $M R D$-negativitása esetén javasolja a csontvelői minta MRD-meghatározását a vérből kapott eredmény validálásaként [6]. A CLL-ben érintett többi kompartment (lép, nyirokcsomó) MRD-vizsgálatával kapcsolatban nincsenek irodalmi adatok. Mivel a CLL egy több kompartmentet érintő betegség, ezért a lép és nyirokcsomóminták vizsgálata az MRD pontosabb meghatározásához vezethetne [25]. Mivel sem a lép, sem az összes nyirokcsomó teljes feldolgozása nem lehetséges, ezért FCM-módszerrel ezekben a szövetekben lévő összes CLL-sejt megtalálására nincsen lehetőség. Többek között ennek következtében egy minden kompartmentre kiterjedő MRD-meghatározás jelenleg nem megvalósítható.

\section{Összefoglalás}

$\mathrm{Az}$ irodalmi adatok áttekintését követően kijelenthető, hogy az MRD meghatározása jelenleg CLL-ben nem képezi a rutindiagnosztika részét. Azonban több klinikai vizsgálat is megmutatta, hogy a jelenlegi kezelésekkel (pl.: RFC, alemtuzumab, venetoclax, ibrutinib-venetoclax) elérhető olyan alacsony tumorsejtszám, melynél a jelenleg a rutindiagnosztikában használt panelek nem kel- lően érzékenyek, azonban MRD-vizsgálattal detektálhatók a CLL-sejtek. Az MRD-státusz bizonyos esetekben érzékenyebben képes jelezni a remisszió mértékét, mint a rutinban jelenleg használt terápiás végpontok (CR, $P R)$. Az MRD-negatív esetekben hosszabb a betegek progreszsziómentes és teljes túlélése, és az MRD-státusz meghatározása alkalmas lehet a terápia hatékonyságának értékelésére, és segítheti a terápiás döntés meghozását olyan kezelés esetén, amelynél a drasztikus tumorsejtszám-csökkenés miatt a rutinpanelek nem kellően szenzitívek. Amennyiben a jelenleg még futó klinikai vizsgálatok eredményei indokolttá teszik az MRD vizsgálatát, akkor ennek áramlási citometriai meghatározása a rutindiagnosztika részévé válhat.

Nyilatkozat: A kézirat korábban más folyóiratokban nem jelent meg, és máshova beküldésre nem került. A levelezőszerző elolvasta a Hematológia-Transzfuziológia szerzői útmutatóját.

Érdekeltségek: A szerzőknek a közleményhez kapcsolódó közvetlen érdekeltségeik nincsenek.

Anyagi támogatás: A közlemény megírásához kapcsolódó munkát a Semmelweis Kutatási és Innovációs Alap, STIAKF-17/24/2017 és a Magyar Nemzeti Kutatási, Fejlesztési és Innovációs Iroda (NFKIH) NVKP_16-1-2016-0004 pályázata támogatta.

Szerzői munkamegosztás: T.F., K.I. - irodalomkutatás, szükséges kísérletek elvégzése a közlemény megírása, C.Á., A.D., Sz.G. - a közlemény lektorálása, I.S., B.A., G.-W.J. - betegminták küldése, B.G. - a kísérletek megtervezése. A cikk végleges változatát valamennyi szerző elolvasta és jóváhagyta.

\section{Irodalom}

[1] Vuillier F, et al. Evaluation of residual disease in B-cell chronic lymphocytic leukemia patients in clinical and bone-marrow remission using CD5-CD19 markers and PCR study of gene rearrangements. Leuk Lymphoma 1992; 7(3): 195-204.

[2] Rawstron AC, et al. Quantitation of minimal disease levels in chronic lymphocytic leukemia using a sensitive flow cytometric assay improves the prediction of outcome and can be used to optimize therapy. Blood 2001; 98(1): 29-35.

[3] Hillmen P, et al. Alemtuzumab compared with chlorambucil as first-line therapy for chronic lymphocytic leukemia. J Clin Oncol. 2007; 25(35): 5616-5623.

[4] Böttcher S, et al. Minimal residual disease quantification is an independent predictor of progression-free and overall survival in chronic lymphocytic leukemia: a multivariate analysis from the randomized GCLLSG CLL8 trial. J Clin Oncol. 2012; 30(9): 980988.

[5] Stilgenbauer S, et al. Venetoclax for patients with chronic lymphocytic leukemia with $17 \mathrm{p}$ deletion: Results from the full population of a phase II pivotal trial. J Clin Oncol. 2018; 36(19): 1973-1980.

[6] Hallek M, et al. iwCLL guidelines for diagnosis, indications for treatment, response assessment, and supportive management of CLL. Blood 2018; 131(25): 2745-2760.

[7] Kwok M, et al. Minimal residual disease is an independent predictor for 10-year survival in CLL. Blood 2016; 128(24): 2770-2773. 
[8] Eichhorst B, et al. First-line chemoimmunotherapy with bendamustine and rituximab versus fludarabine, cyclophosphamide, and rituximab in patients with advanced chronic lymphocytic leukaemia (CLL10): an international, open-label, randomised, phase 3, non-inferiority trial. Lancet Oncol. 2016; 17(7): 928-942.

[9] Geisler $\mathrm{CH}$, et al. Frontline low-dose alemtuzumab with fludarabine and cyclophosphamide prolongs progression-free survival in high-risk CLL. Blood 2014; 123(21): 3255-3262.

[10] Roberts AW, et al. Targeting BCL2 with venetoclax in relapsed chronic lymphocytic leukemia. N Engl J Med. 2016; 374(4): 311-322.

[11] Seymour JF, et al. Venetoclax-rituximab in relapsed or refractory chronic lymphocytic leukemia. N Engl J Med. 2018; 378(12): 1107-1120.

[12] Hallek M, et al. Guidelines for the diagnosis and treatment of chronic lymphocytic leukemia: a report from the International Workshop on Chronic Lymphocytic Leukemia updating the National Cancer Institute - Working Group 1996 guidelines. Blood 2008; 111(12): 5446-5456.

[13] Kovacs G, et al. Minimal residual disease assessment improves prediction of outcome in patients with chronic lymphocytic leukemia (CLL) who achieve partial response: Comprehensive analysis of two phase III studies of the German CLL Study Group. J Clin Oncol. 2016; 34(31): 3758-3765.

[14] Ghia P, Rawstron A. Minimal residual disease analysis in chronic lymphocytic leukemia: A way for achieving more personalized treatments. Leukemia 2018; 32(6): 1307-1316.

[15] European Medicines Agency. Guideline on the use of minimal residue disease as an endpoint in chronic lymphocytic leukaemia studies. 2014. https://www.ema.europa.eu/en/documents/ scientific-guideline/guideline-use-minimal-residue-diseaseendpoint-chronic-lymphocytic-leukaemia-studies_en.pdf

[16] Thompson PA. MRD negativity as a surrogate for PFS in CLL? Blood 2018; 131(9): 943-944.

[17] Dimier N, et al. A model for predicting effect of treatment on progression-free survival using MRD as a surrogate end point in CLL. Blood 2018; 131(9): 955-962.

[18] Fürstenau M, et al. Minimal residual disease assessment in CLL: Ready for use in clinical routine? Hemasphere 2019; 3(5): e287.

[19] Burger JA, et al. Ibrutinib as initial therapy for patients with chronic lymphocytic leukemia. N Engl J Med. 2015; 373(25): 2425-2437.

[20] Shanafelt TD, et al. ibrutinib-rituximab or chemoimmunotherapy for chronic lymphocytic leukemia. N Engl J Med. 2019; 381(5): 432-443.

[21] Fraser G, et al. Updated results from the phase 3 HELIOS study of ibrutinib, bendamustine, and rituximab in relapsed chronic lymphocytic leukemia/small lymphocytic lymphoma. Leukemia 2019; 33(4): 969-980.

[22] Ahn IE, et al. Depth and durability of response to ibrutinib in CLL: 5-year follow-up of a phase 2 study. Blood 2018; 131(21): 2357-2366.

[23] Hillmen P, et al. Ibrutinib plus venetoclax in relapsed/refractory chronic lymphocytic leukemia: The CLARITY study. J Clin Oncol. 2019; JCO1900894.
[24] Thompson PA, et al. Fludarabine, cyclophosphamide, and rituximab treatment achieves long-term disease-free survival in IGHV-mutated chronic lymphocytic leukemia. Blood 2016; 127(3): 303-309.

[25] Thompson PA, Wierda WG. Eliminating minimal residual disease as a therapeutic end point: working toward cure for patients with CLL. Blood 2016; 127(3): 279-286.

[26] Rawstron AC, et al. A complementary role of multiparameter flow cytometry and high-throughput sequencing for minimal residual disease detection in chronic lymphocytic leukemia: a European Research Initiative on CLL study. Leukemia 2016; 30(4): 929-936.

[27] Rawstron AC, et al. International standardized approach for flow cytometric residual disease monitoring in chronic lymphocytic leukaemia. Leukemia 2007; 21(5): 956-964.

[28] Logan AC, et al. Minimal residual disease quantification using consensus primers and high-throughput IGH sequencing predicts post-transplant relapse in chronic lymphocytic leukemia. Leukemia 2013; 27(8): 1659-1665.

[29] Farina L, et al. Qualitative and quantitative polymerase chain reaction monitoring of minimal residual disease in relapsed chronic lymphocytic leukemia: early assessment can predict long-term outcome after reduced intensity allogeneic transplantation. Haematologica 2009; 94(5): 654-662.

[30] Böttcher S, et al. Comparative analysis of minimal residual disease detection using four-color flow cytometry, consensus IgH-PCR, and quantitative IgH PCR in CLL after allogeneic and autologous stem cell transplantation. Leukemia 2004; 18(10): 1637-1645.

[31] Rawstron AC, et al. Improving efficiency and sensitivity: European Research Initiative in CLL (ERIC) update on the international harmonised approach for flow cytometric residual disease monitoring in CLL. Leukemia 2013; 27(1): 142-149.

[32] Sartor MM, Gottlieb DJ. A single tube 10-color flow cytometry assay optimizes detection of minimal residual disease in chronic lymphocytic leukemia. Cytometry B Clin Cytom. 2013; 84(2): 96-103.

[33] Dowling AK, et al. Optimization and validation of an 8-color single-tube assay for the sensitive detection of minimal residual disease in B-cell chronic lymphocytic leukemia detected via flow cytometry. Lab Med. 2016; 47(2): 103-111.

[34] Stehlíková O, et al. Detecting minimal residual disease in patients with chronic lymphocytic leukemia using 8-color flow cytometry protocol in routine hematological practice. Int J Lab Hematol. 2014; 36(2): 165-171.

[35] Abrisqueta P, et al. Rituximab maintenance after first-line therapy with rituximab, fludarabine, cyclophosphamide, and mitoxantrone (R-FCM) for chronic lymphocytic leukemia. Blood 2013; 122(24): 3951-3959.

[36] Fischer K, et al. Bendamustine in combination with rituximab for previously untreated patients with chronic lymphocytic leukemia: a multicenter phase II trial of the German Chronic Lymphocytic Leukemia Study Group. J Clin Oncol. 2012; 30(26): 3209-3216.

[37] Li J, et al. Population pharmacokinetics of rituximab in patients with chronic lymphocytic leukemia. J Clin Pharmacol. 2012; 52(12): 1918-1926.

A cikk a Creative Commons Attribution 4.0 International License (https://creativecommons.org/licenses/by/4.0/) feltételei szerint publikált Open Access közlemény, melynek szellemében a cikk bármilyen médiumban szabadon felhasználható, megosztható és újraközölhető, feltéve, hogy az eredeti szerző és a közlés helye, illetve a CC License linkje és az esetlegesen végrehajtott módosítások feltüntetésre kerülnek. (SID_1) 